Katedra Prawa Pracy

Wydział Prawa i Administracji

Uniwersytet Łódzki

\title{
OCENA SYTUACJI PRAWNEJ STARSZYCH PRACOWNIKÓW I OSÓB STARSZYCH POSZUKUJĄCYCH PRACY NA LITWIE
}

\begin{abstract}
Assessment of the legal status of elderly workers and elderly people seeking work in Lithuania
\end{abstract}

The study investigates the influence of legal statutory regulations in the area of employment permanence, non-discrimination principle on the base of age and legal instruments that strengthen the efforts undertaken to combat unemployment among older people. Accordingly to the results of study based on statistical data and legal analysis of law provisions, Author presents some considerations related to the significance of legal instruments provided in Lithuanian statutory regulations. The presented paper is also written in an attempt to provide some conclusions that will be used at the final monograph entailing the research results concerning the model of legal instruments.

Słowa kluczowe: bezrobocie, starsi pracownicy, rynek pracy, przeciwdziałanie bezrobociu, zakaz dyskryminacji ze względu na wiek starszy

Key words: unemployment, older employees, labour market, combating of unemployment, nondiscrimination on the base of old age

\section{Wprowadzenie}

Konstrukcja Indeksu Aktywnego Starzenia się, oparta na wybranych obszarach podlegających indeksacji, pozwala nie tylko ocenić sytuację państw z punktu widzenia stosowanych środków polityki aktywnego starzenia się, lecz również umożliwia porównanie zmian, jakie są dokonywane w omawianym zakresie. Powyższy indeks zawiera dane występujące w sferze zatrudnienia, integracji ze społeczeństwem, niezależnego oraz zdrowego życia oraz aktywnego starzenia się. Poniżej zaprezentowane dane stanowią wyniki badań w ramach projektu pod kierunkiem Generalnego Dyrektoriatu ds. Zatrudnienia, Inkluzji 
i Polityki Społecznej Komisji Europejskiej oraz Komitetu ds. Ekonomicznych Europy Organizacji Narodów Zjednoczonych ${ }^{1}$.

Gdy chodzi Litwę, w ogólnej skali wśród państw EU-28 zajmuje ona 19. miejsce, znajdując się powyżej Polski (27. miejsce), Słowacji (26. miejsce), Węgier (25. miejsce), Łotwy (20. miejsce), ale też poniżej Czeskiej Republiki (12. miejsce) i Estonii (11. miejsce). W zakresie wskaźników zatrudnienia Litwa prezentuje się na 13. miejscu, sytuując się powyżej Republiki Czeskiej (14. miejsce), Polski (20. miejsce), Słowacji (21. miejsce) i Węgier (27. miejsce). Jednakże w zakresie aktywnego starzenia się - wskaźnika opartego na indywidualnej charakterystyce osób starszych - Litwa wypada dość niekorzystnie, zajmując przedostatnie, 27. miejsce. Lepiej od Litwy w omawianym zakresie prezentują się Słowacja (24. miejsce), Estonia (23. miejsce), Polska (22. miejsce), Łotwa (21. miejsce) oraz Republika Czeska (14. miejsce). W ramach pozostałych wskaźników Litwa zajmuje 19. miejsce, gdy chodzi o integrację osób starszych ze społeczeństwem, natomiast 22. miejsce w odniesieniu do ich niezależnego życia. Polska w powyższym zakresie zajmuje odpowiednio 28. i 24. miejsce. Gorzej od Litwy wypada Łotwa (23. i 28. miejsce), po części Estonia (25. i 20. miejsce), natomiast zdecydowanie wyższe miejsce zajmuje Czeska Republika (12. i 13. miejsce) oraz Węgry (18. i 18. miejsce).

Zgodnie z krajowymi danymi statystycznymi Litwa w coraz większym natężeniu przeżywa proces starzenia się ludności. Udział osób w podeszłym wieku (w wieku 65 lat i starszym) w ogólnej liczbie populacji wzrasta, podczas gdy ogólna liczba ludności maleje. Zgodnie z prezentowanymi przez Litewski Urząd Statystyczny informacjami na początku 2014 r. Litwa miała $2 \mathrm{mln} 943,5$ tys. mieszkańców, z czego 542,7 tys. (18,4\%) było w wieku 65 lat i wyższym. W ciągu ostatnich dziesięciu lat (2004-2013) ich liczba wzrosła o 18,6 tys. (3,5\%), a ich udział w ogólnej liczbie ludności podniósł się o 3 punkty procentowe, podczas gdy liczba ludności zmniejszyła się o 455,5 tys. (13,4\%). Zauważa się również, że liczba starszych kobiet jest prawie dwa razy wyższa niż starszych mężczyzn. Na początku 2014 r. w kraju było 182,4 tys. (33,6\%) mężczyzn i 360,3 tys. (66,4\%) kobiet w wieku 65 lat i starszych. Przewiduje się, że na początku 2050 r. Litwa będzie miała około dwóch milionów ( 1 mln 910 tys.) mieszkańców, z czego ponad pół miliona ( 544,5 tys.) lub 28,5\% ogółu ludności będą stanowiły osoby starsze. Dla porównania, gdy chodzi o rok 2013, w Unii Europejskiej 18,2\% mieszkańców stanowily osoby w wieku 65 lat i starsze. Wyższe wskaźniki występowały we Włoszech $(21,2 \%)$, Niemczech $(20,7 \%)$, w Grecji (20,1\%) i Portugalii (19,4\%), najniższe - w Irlandii (12,2\%), na Słowacji (13,1\%) i na Cyprze (13,2\%). Wskazuje się, że w 2014 r. co siódmy mężczyzna i co szósta kobieta przekroczyli wiek 65 lat $^{2}$.

1 http://www.unece.org/fileadmin/DAM/pau/age/WG7/Documents/Policy_Brief_AAI_for_EG_ v2.pdf (dostęp: 31.01.2016).

2 Powyższe dane zostały przedstawione przez G. Burokaitè, http://ec.europa.eu/eurostat/web/ess/-/ elderly-people-in-lithuania (dostęp: 31.01.2016). Powyższe dane przedstawia także opracowanie Pagyvene zmones Lietiuvoje, Elderly People in Lithuania, Statistics Lithuania, Vilnius 2014, s. 8, https://osp.stat.gov. lt/services-portlet/pub-edition-file?id=3030 (dostęp: 31.01 .2016 ). 
Powyższe dane potwierdzają nie tylko wydłużenie się średniej życia, lecz także potrzebę zapewnienia jak najdłuższego pozostania osób starszych na rynku pracy: chodzi zarówno o osoby w wieku przedemerytalnym, jak i samych emerytów. Ocena sytuacji starszych osób na litewskim rynku pracy³, przeprowadzona w 2013 r., wykazała, że wśród głównych barier w zakresie dłuższego pozostawania na rynku pracy osób starszych wymieniano:

- niewystarczające możliwości stosowania elastycznych rozwiązań, ponieważ Kodeks pracy Republiki Litewskiej nie przewiduje szczególnych rozwiązań powiązanych z krótszym czasem pracy osób starszych;

- nie występują unormowania prawne dotyczące pracy w niepełnym wymiarze czasu pracy dla starszych pracowników;

- warunki pracy nie są dostosowywane do możliwości osób starszych;

- brak zainteresowania podwyższaniem kwalifikacji oraz kształceniem ustawicznym (w 2010 r. wskaźnik udziału osób w wieku 55-74 lata w kształceniu ustawicznym (LLL) na Litwie był sześć razy niższy w porównaniu ze średnią UE);

- brak usług rynku pracy adresowanych wyłącznie do osób starszych;

- negatywne nastawienie pracodawców do osób starszych ze względu na ich niższe kwalifikacje, brak znajomości języków obcych;

- problemy zdrowotne, brak motywacji, obawy przed zmianami i nowymi wyzwaniami.

Zauważono, że zarówno rząd litewski, jak i partnerzy społeczni są zbyt słabo zaangażowani w działania na rzecz pozostania w zatrudnieniu przez powyższe osoby starsze. Powinni zatem podejmować bardziej znaczące inicjatywy w dziedzinie polityki przedłużającej aktywność zawodową poprzez poprawę jakości pracy i utrzymanie starszych pracowników na rynku pracy. Podkreślono także, że działający od ponad 10 lat Bank Seniorów - baza internetowa zawierająca dane osób starszych poszukujących pracy (chodzi o osoby powyżej 50. roku życia oraz osoby w wieku emerytalnym) - w 2013 r. potwierdzał zbyt małą liczbę osób zainteresowanych pozyskaniem pracy ${ }^{4}$.

\section{Kodeksowe unormowania odnoszące się do osób w wieku starszym}

Trwająca od kilku lat burzliwa dyskusja w przedmiocie zmian w litewskim prawie pracy poskutkowała wydaniem nowego kodeksu pracy. Nowy Kodeks pracy (lkp) został

3 R. Zabarauskaite, I. Blaziene, European Observatory of Working Life, Lithuania: The Role of Governments and Social Partners in Keeping Older Workers in the Labour Market, opublikowano 2.06.2013 r., http://www.eurofound.europa.eu/observatories/eurwork/comparative-information/national-contributions/lithuania-the-role-of-governments-and-social-partners-in-keeping-older-workers-inthe-labour-market (dostęp: 31.01.2016).

4 Brakuje szczegółowych badań na temat efektywności tego środka jako instrumentu umożliwiającego powrót osób starszych na rynek pracy. 
uchwalony przez parlament litewski 14 września 2016 r. ${ }^{5}$ Wszedł w życie 1 stycznia 2017 r. Głównym celem zmian była liberalizacja stosunków zatrudnieniowych oraz wprowadzenie elastycznych rozwiązań w zakresie wykonywania pracy, a także zwiększenie roli partnerów społecznych ${ }^{6}$. Zdaniem przedstawicieli nauki dotychczas obowiązujący kodeks nie odpowiadał aktualnym uwarunkowaniom ekonomiczno-społecznym oraz jako oderwany od realiów rynkowych był zbyt „sztywny” i nadmiernie sformalizowany. Nie odpowiadał też potrzebom zarówno pracowników, jak i pracodawców ${ }^{7}$. Zauważano także, że gdy chodzi o osoby w wieku przedemerytalnym, możliwość ponownego podjęcia pracy przez osoby w tym przedziale wiekowym praktycznie nie istniała ${ }^{8}$.

Spośród wprowadzonych zmian na szczególną uwagę zasługują te z nich, które mogą być przydatne z punktu widzenia zatrudnienia starszych pracowników. Dotyczy to zwłaszcza zawierania terminowych umów o pracę, elastycznych rozwiązań w zakresie czasu pracy, warunków zwolnień, niedyskryminacji oraz wzmocnienia roli porozumień zbiorowych'.

W sposób istotny zmieniono przepisy dotyczące rodzajów umów o pracę. Poza tradycyjnie wyodrębnianymi umowami bezterminowymi i terminowymi wyróżniono umowę „zero godzin”, umowę o pracę tymczasową, umowę, w ramach której stanowisko pracy jest dzielone przez kilku pracowników, umowę zawieraną z kilkoma pracodawcami, umowę o pracę sezonową oraz umowę o pracę projektową. $Z$ punktu widzenia zatrudnienia osób w wieku starszym poza umowami terminowymi z pewnością na szczególną uwagę zasługują umowy dotyczące dzielenia stanowiska pracy, pracy tymczasowej oraz telepracy. Dzielenie stanowiska pracy regulują przepisy art. 93-95 lkp. Wniosek o stosowanie tej formy pracy w pewnych sytuacjach uznano za wiążący dla pracodawcy. Ustawodawca wskazuje tu na osoby opiekujące się dzieckiem do lat siedmiu. Wśród uprzywilejowanych pracowników nie występują jednak osoby w wieku emerytalnym bądź przedemerytalnym. Ponadto na uwagę zasługują także uregulowania prawne dotyczące telepracy (art. $52 \mathrm{lkp}$ ). Instytucja ta może być zwłaszcza przydana dla osób obarczonych obowiązkami rodzinnymi. Również w tym przypadku wniosek pochodzący od określonych osób wskazanych przez ustawodawcę co do zasady musi być uwzględniony przez pracodawcę. Ustawodawca wskazuje w tym zakresie na kobiety w ciąży, osoby opiekujące się dzieckiem do lat trzech, pomijając jednakże osoby w wieku starszym.

5 Nr XII-2603. Tekst nowego kodeksu dostępny na stronie: https://e-seimas.lrs.lt/portal/legalAct/ en/TAD/TAIS.191770 (dostęp: 1.07.2017).

6 D. Petrylaite, Four year of Lithuanian labour reforms, Lithuanian national report, International Society for Labour and Social Security 2014, s. 8, 9, http://islssl.org/wp-content/uploads/2014/08/ Lithuanian-National-Report.pdf (dostęp: 1.07.2017).

7 T. Baginskas, J. Usonis, Problems of introduction offlexibility into lithuanian labour law, Jurisprudence 2011, 18 (2), s. 595-612.

8 Tamże.

9 Porównanie wprowadzonych zmian z dotychczas obowiązującymi przepisami jest dostępne na stronie: https://leinonen.lt/naujienos/naujienos-2016/naujas-darbo-kodeksas-nuo-2017-m (dostęp: 1.07.2017). 
Gdy chodzi o umowy terminowe, zgodnie z kodeksem pracy mogą one być co do zasady zawierane na okres dwóch lat (art. 67-71 lkp). Do czasu wejścia w życie nowego kodeksu pracy termin był pięcioletni. Obecnie okres ten może wchodzić w rachubę tylko w sytuacjach wyjątkowych. Dotyczy to przypadków łącznego powierzenia różnych prac na podstawie terminowych umów o pracę. Wprowadzono także okres wypowiedzenia, który dotychczas przy umowach terminowych nie występował. Zróżnicowano go w zależności od okresu zatrudnienia: pięciodniowy okres wypowiedzenia obejmuje pracowników zatrudnionych na czas określony od roku wzwyż, natomiast dziesięciodniowy dotyczy tych pracujących powyżej trzech lat. Nowością jest także wypłata odprawy w wysokości jednomiesięcznego wynagrodzenia, jeżeli pracownik był zatrudniony przez okres co najmniej dwóch lat. Co ciekawe, zezwolono na zawieranie umów na czas określony w celu wykonania prac, które mają stały charakter oraz dla których tradycyjnie zawierane są umowy na czas nieokreślony ${ }^{10}$. Warunkiem ich zawierania jest jednak to, by liczba takich umów nie przekroczyła $20 \%$ ogółu umów zawieranych w zakładzie pracy. W powyższym zakresie nie występują jednak unormowania szczególne, ułatwienia bądź odstępstwa odnoszące się ściśle do starszych pracowników.

Według przepisów starego kodeksu pracy zwolnienia pracowników bez ich winy z inicjatywy pracodawcy były dopuszczalne wyłącznie ze względu na ważne przyczyny. Obecnie art. $57 \mathrm{lkp}$ stanowi, że rozwiązanie przez pracodawcę umowy o pracę bez winy pracownika może nastąpić z powodu przyczyn wyszczególnionych przez ustawodawcę. Zalicza się do nich między innymi zmiany organizacyjne w pracy, nieosiągnięcie ustalonych wyników pracy przez pracownika, odmowę wykonywania przez pracownika pracy na zmienionych warunkach, odmowę wykonywania pracy przez pracownika w związku ze zmianą pracodawcy oraz zakończenie działalności przez pracodawcę. W razie doboru pracowników do zwolnień przepis wskazuje, że pierwszeństwo pozostania w zatrudnieniu przysługuje pracownikom, którym do wieku emerytalnego brakuje nie więcej niż trzy lata. Powyższym unormowaniem objęto także członków rodziny osiągających wiek emerytalny, o ile mają ustalony znaczny albo średni stopień niepełnosprawności. Podkreślenia wymaga, że ustawodawca posługuje się w tym miejscu pojęciem wieku emerytalnego, a nie nabyciem uprawnień emerytalnych. Dodatkowo z pierwszeństwa pozostania $\mathrm{w}$ zatrudnieniu korzystają także osoby $\mathrm{z}$ dłuższym stażem pracy. Chodzi tu o co najmniej dziesięciomiesięczny nieprzerwany staż zakładowy. Nie dotyczy to jednak tych pracowników, którzy osiągnęli wiek emerytalny oraz nabyli prawo do pełnej emerytury starczej. Ponadto pierwszeństwo pozostania w zatrudnieniu będzie przysługiwało także tym osobom, na które wskaże porozumienie zbiorowe. Widzieć w tym można pewną szansę także dla starszych pracowników.

Dotychczas obowiązujące okresy wypowiedzenia (dwu- i czteromiesięczne) także uległy zmianom. Okres wypowiedzenia zróżnicowano, biorąc pod uwagę staż pracy oraz

10 Wcześniej taka praktyka była wyraźnie zakazana, zob. o tym D. Petrylaite, Four year of Lithuanian..., s. 4. 
wiek przedemerytalny. Jednomiesięczny okres wypowiedzenia uznano za standardowy. Dwutygodniowy okres dotyczy pracowników zatrudnionych przez okres do jednego roku w zakładzie pracy. Terminy te ulegają podwojeniu w sytuacji opieki nad dzieckiem do lat 14 oraz w przypadku osób, którym brakuje nie więcej niż pięć lat do osiągnięcia wieku emerytalnego. Z kolei potrojenie powyższych okresów wchodzi w rachubę w odniesieniu do tych osób starszych, którym brakuje nie więcej niż dwa lata do osiągnięcia wieku emerytalnego. Powyższe dotyczy też pracowników niepełnosprawnych (art. 57 lkp).

Odprawa w związku ze zwolnieniem z przyczyn niezawinionych przez pracownika była zróżnicowana według stażu pracowniczego oraz wynosiła od jednego do sześciu średnich wynagrodzeń. Obecnie, pomimo pozostawienia stażu pracy jako kryterium wpływającego na wysokość odprawy, zmieniono jej wysokość. Pracodawca co do zasady wypłaca odprawę w wysokości dwumiesięcznego wynagrodzenia. Połowę wynagrodzenia tytułem odprawy wypłaca jednak pracownikom zatrudnionym przez okres krótszy niż rok. Co ciekawe, przy dłuższym stażu pracy wchodzi w rachubę obowiązek wypłacenia odprawy dodatkowej przez instytucję państwową. Wypłaca ona odprawę w wysokości trzymiesięcznego wynagrodzenia osobom posiadającym ponad 20-letni staż pracy. Przy stażu od 10 do 20 lat odprawę ustala się w wysokości dwukrotności wynagrodzenia za pracę, z kolei przy stażu od 5 do 10 lat - w wysokości jednomiesięcznego wynagrodzenia.

W razie rozwiązania umowy o pracę przez pracodawcę z innych powodów niż wyżej określone (z wyłączeniem powodów, o których mowa w art. $57 \mathrm{lkp}$ ) ma on obowiązek wyplacić odprawę równą sześciomiesięcznemu wynagrodzeniu pracownika. Okres wypowiedzenia wynosi wówczas jednak tylko trzy dni robocze. Przy czym wypowiedzenie umowy nie może nastąpić z przyczyn uznanych za dyskryminujące, wśród których wskazuje się także wiek (art. $59 \mathrm{lkp}$ ). Podkreślenia wymaga okoliczność, iż z powyższego rozwiązania mogą skorzystać tylko niektórzy pracodawcy. Nie dotyczy to państwowych oraz samorządowych jednostek budżetowych oraz innych, finansowanych ze środków publicznych.

Nieco inaczej uregulowano wypowiadanie umów z inicjatywy pracownika. W razie wypowiadania bezterminowej umowy o pracę oraz umowy terminowej zawartej na okres dłuższy niż miesiąc pracownika obowiązuje dwudziestodniowy okres wypowiedzenia (art. $55 \mathrm{lkp}$ ). Z kolei rozwiązanie umowy z zachowaniem tylko pięciodniowego okresu wypowiedzenia dopuszczalne jest przez pracownika wyłącznie z ważnych powodów. Dotyczy to sytuacji, w której pracownik zatrudniony bezterminowo osiąga wiek emerytalny oraz w czasie zatrudnienia u danego pracodawcy nabywa prawo do pełnej emerytury starczej (art. 56 ust. 1 pkt 4 lkp). Rozwiązanie umowy o pracę w tym trybie obliguje pracodawcę także do wypłacenia odprawy w wysokości jednomiesięcznego wynagrodzenia.

Dość istotne zmiany wystąpiły w zakresie uregulowań dotyczących czasu pracy. Dotyczy to również pracy w niepełnym wymiarze czasu pracy (art. $40 \mathrm{lkp}$ ). Zgodnie z tym artykułem osoby zatrudnione przez okres co najmniej trzech lat mają prawo żądania zamiany pełnego wymiaru czasu pracy na niepełny. Polegać to może albo na skróceniu dobowego czasu pracy do czterech godzin dziennie, albo na zmniejszeniu liczby dni wykonywania pracy w tygodniu do trzech. Pracodawca powinien uwzględnić 
wniosek pracownika, jeżeli składany jest on na 30 dni przed wprowadzeniem planowanej zmiany, a praca w niepełnym wymiarze będzie obejmowała okres do jednego roku. Może też nie wyrazić zgody na zmianę wymiaru czasu pracy ze względu na ważne powody. Ponadto pod pewnymi warunkami możliwe jest również ponowne wnioskowanie o pracę w niepełnym wymiarze czasu pracy. Ograniczenia dotyczące długości pracy w niepełnym wymiarze czasu pracy oraz powyższe warunki nie będą stosowane do określonych kategorii pracowników. Wśród nich wymieniono osoby mające obowiązki rodzicielskie, pracowników sprawujących pieczę nad zależnym członkiem rodziny, a także osoby, których stan zdrowia potwierdzony jest zaświadczeniem ze stosownej instytucji, oraz osoby niepełnosprawne.

Wśród wprowadzonych rozwiązań interesujące są także uregulowania w zakresie wynagrodzenia minimalnego (art. $141 \mathrm{lkp}$ ). Przewidzieć je można tylko w odniesieniu do prac niewymagających szczególnych kwalifikacji zawodowych albo doświadczenia zawodowego. Przy czym w układach zbiorowych pracy można takie wynagrodzenie podwyższać. Z perspektywy starszych pracowników, wyróżniających się częstokroć bardzo bogatym życiorysem zawodowym, takie rozwiązanie wydaje się mieć szczególne znaczenie.

Przedstawione uwagi ukazują dość ograniczoną treść przepisów odnoszących się stricte do zatrudnienia starszych pracowników. Wiek starszy tylko w nieznacznym stopniu daje przywileje pracownikom. Chodzi tutaj o pierwszeństwo pozostania w zatrudnieniu w sytuacji zwolnień oraz dłuższe okresy wypowiedzenia. Osiągnięcie wieku emerytalnego oraz nabycie prawa do pełnej emerytury starczej uznano za powód wyłączający z pierwszeństwa pozostania w zatrudnieniu. Z kolei ta sama okoliczność jest przez ustawodawcę traktowana jako powód rozwiązania umowy o pracę przez pracownika z zachowaniem pięciodniowego okresu wypowiedzenia z obowiązkiem wypłacenia mu jednomiesięcznej odprawy.

W pewnych sytuacjach, aczkolwiek nie są one znaczne, ustawodawca uprzywilejowuje osoby mające problemy zdrowotne albo ustalony stopień niepełnosprawności. Widać to na przykładzie pracy w niepełnym wymiarze czasu pracy albo pracy w charakterze telepracownika, a także w zakresie udzielania urlopów wypoczynkowych, gdy chodzi o ich długość oraz pierwszeństwo rozpatrywania wniosku o urlop (art. 128 lkp). Uprzywilejowane, jakkolwiek tylko w pewnym zakresie, są osoby mające obowiązki rodzinne. W przeważającej większości dodatkowe ułatwienia dotyczą jednak osób z obowiązkami rodzicielskimi.

Staż pracy jako kryterium uprzywilejowujące występuje w przepisach dotyczących okresów wypowiedzenia oraz odpraw z tytułu zwolnień. Kryterium dłuższego stażu pracy brane jest pod uwagę również przy okazji oceny pierwszeństwa pozostania w zatrudnieniu. Ponadto staż pracy w razie sporu na skutek uzyskania przez kandydatów do rady pracowników takiej samej liczby głosów rozstrzyga o wyborze kandydata do rady (art. $171 \mathrm{kp})$.

Pozostałe przepisy nowego Kodeksu pracy dotyczące elastycznych form i podstaw wykonywania pracy odnoszą się do ogółu pracowników. Mimo iż nie występują w tym zakresie unormowania skierowane do pracowników w wieku emerytalnym bądź 
przedemerytalnym, trudno zaprzeczyć, iż jako bardziej elastyczne mogą przyczyniać się do zwiększania zatrudnienia także osób z tego przedziału wiekowego.

\section{Zakaz dyskryminacji ze względu na wiek starszy}

W zakresie zakazu dyskryminacji w litewskim Kodeksie pracy występują unormowania o charakterze ogólnym. Na uwagę zasługuje art. 26 określający zakaz dyskryminacji ze względu na niedozwolone kryteria. Wśród tych kryteriów wymieniono wiek bez zaznaczenia, czy chodzi o wiek starszy, czy młodszy. Podobnie podkreślono, że przy rozwiązywaniu umowy o pracę nie można dokonać zwolnienia z powodu wieku albo innych dyskryminujących kryteriów (art. $59 \mathrm{lkp}$ ). Zasadę niedyskryminacji ze względu na wiek przy powierzaniu pracy tymczasowej sformułowano także w art. $73 \mathrm{lkp}$.

Szczegółowe unormowania w omawianym przedmiocie zawiera odrębna ustawa. Zgodnie $\mathrm{z}$ ustawą o równych prawach $\mathrm{z}$ dnia 18 listopada $2003 \mathrm{r}^{11}{ }^{11}$ zakazana jest dyskryminacja bezpośrednia oraz pośrednia ze względu na wiek. Ustawodawca nie wskazuje jednak na wiek starszy. Ustawa ma szeroki zakres zastosowania, wykracza też poza stosunki zatrudnienia. Artykuł 5 przedmiotowej ustawy określa obowiązki pracodawcy $\mathrm{w}$ zakresie stosowania równych praw $\mathrm{w}$ pracy. $\mathrm{W}$ tym celu pracodawca bez względu na wiek stosuje jednakowe warunki rekrutacji i zwalniania, dokształcania oraz podwyższania kwalifikacji, a także jednakowe kryteria oceniania pracowników. Za naruszenie zasady równych praw uważa się postępowanie, gdy ze względu na wiek stosuje się mniej (bardziej) dogodne kryteria zatrudnienia, gdy za taką samą bądź podobną pracę wypłaca się różne wynagrodzenie albo stwarza się mniej (bardziej) przychylne możliwości przekwalifikowania się, podwyższania kwalifikacji, a także stosuje się kary, zmienia się warunki pracy, powierza się inną pracę bądź zwalnia się z pracy (artykuł 7 ustawy). Za dyskryminujące uważa się także ogłoszenia o pracę, w których stwarza się pierwszeństwo w zatrudnieniu dla osób określonego wieku (art. 10 ustawy). Powyższe unormowanie zasługuje na szczególnie pozytywne podkreślenie, ponieważ w przeprowadzonych badaniach zauważono, że połowa ankietowanych wskazywała na ogłoszenia jako zasadnicze czynniki wyłączające osoby starsze z kręgu osób ubiegających się o miejsca pracy ${ }^{12}$.

Osoba, która czuje się pokrzywdzona oraz uważa, że w stosunku do niej były stosowane zachowania dyskryminujące bądź względem niej dopuszczono się molestowania, zanim wkroczy na drogę postępowania sądowego, ma prawo zwrócenia się do Inspektora ds. Równych Praw.

11 Lietuvos Respublikos lygių galimybių istatymas 2003 m. Lapkričio 18 d., Nr. Ix-1826, http:// www3.lrs.lt/pls/inter3/dokpaieska.showdoc_l?p_id=454179 (dostęp: 31.01.2016).

12 R. Brazienè, I. Mikutavičienè, A. Dorelaitienė, U. Žalkauskaitė, J. Jurkevičienè, Vyresnio amžiaus žmoniu (socialinés ịtraukites) ì(si)traukimo ị darbo rinką galimybiu atsakaita, 2014 m., www.lygybe.lt (dostęp: 31.01.2016). 
Kompleksowe badanie dotyczące dyskryminacji, w tym dyskryminacji ze względu na wiek, zostało przeprowadzone w 2008 r. Jego wyniki zawarte zostały w opracowaniu dotyczącym naruszenia równych praw w aspekcie wiekowym ${ }^{13}$. Wskazano w nim na częstsze, w porównaniu z pracownikami młodszymi, przypadki dyskryminowania pracowników ze względu na wiek starszy. W odniesieniu do nich dyskryminacja przejawia się między innymi w odmowie zatrudnienia, niższych zarobkach oraz zwolnieniach bez uzasadnionych powodów. Wśród głównych przyczyn dyskryminacji wskazywano też na negatywny stosunek społeczeństwa do osób starszych jako niedołężnych, z problemami zdrowotnymi, trudno dostosowujących się do środowiska pracy. Pozytywnie jednakże zauważono, że z roku na rok liczba skarg z powodu dyskryminacji ze względu na wiek starszy maleje.

W najnowszym raporcie Inspektoratu ds. Równych Praw ${ }^{14}$ dotyczącym dyskryminacji ze względu na wiek wskazano, że szczególnie negatywne stanowisko względem starszych pracowników wyrażają młodsi pracodawcy. Zwłaszcza nieprzechylnie traktuje się tych pracowników, którzy doświadczenie zawodowe nabyli w okresie tak zwanym radzieckim. Pojęcie okresu radzieckiego jest wciąż obecne w wypowiedziach różnych osób oraz ma wydźwięk pejoratywny, również gdy chodzi o doświadczenia zawodowe z tamtego okresu. Ponadto podkreśla się, że osoby starsze kojarzone są ze strachem i obawami przed innowacjami, brakiem umiejętności posługiwania się urządzeniami technicznymi oraz nieznajomością języków obcych. Podkreślono, że w około 50\% dyskryminacja występuje zwłaszcza przy rekrutacji, kształtowaniu warunków zatrudnienia oraz zwolnieniach pracowników. Wskazuje się także na występowanie dyskryminujących ogłoszeń, w których posługiwano się określeniem warunków zatrudnienia poprzez zaadresowanie ogłoszenia do „osoby młodej”. Podobne wyniki, potwierdzające obecność dyskryminacji w mediach (czego przykładem jest reklama zatytułowana „Wszyscy chcieliby być seniorami”) oraz w odbiorze społecznym, przedstawiają dane zawarte w sprawozdaniu dotyczącym badania osób w wieku starszym ${ }^{15}$.

13 G. Navaitis, A. Burneikienė, R. Trinkūnienè, Lygiu galimybiu pažeidimai (amžiaus aspektas), Socialinis Darbas 2008, 7 (3), s. 41-47, https://www.mruni.eu/upload/iblock/5b7/5_navaitis_burneikiene_trinkuniene.pdf (dostęp: 31.01.2016). Zob. też uwagi ogólne na temat ustawodawstwa antydyskryminacyjnego, zawarte w raporcie przygotowanym przez ekspertów na zlecenie Komisji Europejskiej: Age and Employment, wedtug stanu na lipiec 2011 r., dostępny na https://www.age_and_employmen_en.pdf (dostęp: 31.01.2016).

${ }_{14}$ Lygiu galimybiu kontrolieriaus tarnybos veiklos 2014 m. ataskaita, http://www.lygybe.lt/lt/metines-tarnybos-ataskaitos.html (dostęp: 31.01.2016).

15 R. Brazienè, I. Mikutavičienè, A. Dorelaitienè, U. Žalkauskaitè, J. Jurkevičienè, Vyresnio amžiaus žmonių..., s. 107-110, www.lygybe.lt (dostęp: 31.01.2016). 


\section{Środki prawne służące przeciwdziałaniu bezrobociu wśród osób starszych}

Rola publicznych służb zatrudnienia na Litwie nie różni się od tej, jaką odgrywają urzędy polskie. Świadczą pomoc osobom poszukującym pracy, pomagają pracodawcom znaleźć odpowiednio wykwalifikowanych pracowników, zachęcają zarejestrowanych bezrobotnych do udziału w programach na rzecz zatrudnienia, w szkoleniach zawodowych i przekwalifikowaniu się, organizacji własnego biznesu, udziału w pracach interwencyjnych i robotach publicznych. Wspierają przedsiębiorców (pracodawców) w zakresie tworzenia nowych miejsc pracy, a także wypłacają zasiłki dla bezrobotnych.

Główny Urząd Pracy na Litwie działa pod nadzorem Ministerstwa Spraw Społecznych. Na podkreślenie zasługuje, że od 1 października 2010 r., po restrukturyzacji, został wprowadzony nowy model pracy regionalnych biur pracy. Poprzedni model składający się z 46 biur zastąpiono zorientowanymi na klienta lokalnymi biurami pracy. Obecnie, poza Litewskim Urzędem Pracy (Darbo Birża), działa 10 lokalnych biur pracy w największych miastach litewskich ${ }^{16}$.

\section{Kategorie starszych pracowników}

Ustawa o wspieraniu zatrudnienia z dnia 15 czerwca 2006 r. ${ }^{17}$ wyróżnia kilka kategorii bezrobotnych. Zgodnie z nią pod pojęciem bezrobotnego występuje osoba niepracująca $\mathrm{w}$ wieku produkcyjnym, nieucząca się zgodnie $\mathrm{z}$ systemem nauczania podstawowego albo zawodowego albo niestudiująca w szkole wyższej według stałego systemu nauczania, która zarejestrowała się we właściwym rejonowym urzędzie pracy. Z kolei pod pojęciem osoby w wieku produkcyjnym rozumieć należy osoby, które ukończyły 16. rok życia oraz nie osiągnęly wieku emerytalnego, określonego w ustawie emerytalnej. Definicję osoby niepracującej zawiera punkt 13 omawianego artykułu.

Dodatkowym wsparciem na rynku pracy, zgodnie z art. 4 powyższej ustawy, objęto osoby w wieku produkcyjnym powyżej 50. roku życia, o ile są zdolne do pracy. Zabrakło w powyższym zakresie odwołania się do kwalifikacji tych osób jako osób bezrobotnych w rozumieniu ustawy. Zauważyć też należy, że w ramach powyższej ustawy ustawodawca posługuje się również pojęciem osób, którym brakuje nie więcej niż 5 lat do osiągnięcia wieku emerytalnego.

\section{Rodzaje pomocy}

Ustawa o wspieraniu zatrudnienia wyróżnia środki wspierające zatrudnienie oraz usługi rynku pracy. Podkreślenia wymaga, że nie występują instrumenty skierowane wyłącznie do osób starszych. Te same środki są stosowane do różnych grup docelowych. Niemniej, ze względu na kwalifikację osób powyżej 50. roku życia w kategorii tych, które

16 www.eures.praca.gov.pl/zal/warunki_zycia/litwa/litwa.pdf (dostęp: 31.01.2016).

17 LietuvosRespublikosužimtumo rèmimoịstatymas, 2006 m. birželio 15d.,nr.x-694,http://www3.lrs.lt/ pls/inter3/dokpaieska.showdoc_l?p_id=478633 (dostęp: 31.01.2016). 
wymagają dodatkowego wsparcia w rozumieniu art. 4 ust. 1 pkt 7 ustawy o zatrudnieniu, przewidziano albo wyższe dofinansowanie w związku ze stosowaniem poszczególnych instrumentów aktywizacji zawodowej, albo też wydłużono czas wypłaty świadczeń przeznaczonych dla grup szczególnie wspieranych na rynku pracy. Dodać jednak należy, że w ramach szczególnych grup wspieranych na rynku pracy wymieniono osoby, które pozostawały bez pracy przez okres co najmniej dwóch lat przed zarejestrowaniem się w urzędzie pracy (art. 4 ust. 1 pkt 10 przedmiotowej ustawy ${ }^{18}$ ).

Wśród środków wspierających zatrudnienie w oparciu o artykuł 3 ust. 3 uwz należy wyróżnić: środki aktywnej polityki rynku pracy, programy zwiększania zatrudnienia, wolontariat. $Z$ kolei do usług rynku pracy ustawodawca zalicza informację, konsultacje oraz pośrednictwo w poszukiwaniu pracy (art. 3 ust. 4).

Zgodnie z art. 22 ustawy wyróżnia się środki aktywnej polityki rynku pracy, zaliczając do nich: zawodowe przygotowanie osób bezrobotnych, a także osób w wieku produkcyjnym, objętych zwolnieniami, zatrudnienie wspierane, wsparcie na utworzenie miejsca pracy, wspieranie regionalnego przepływu bezrobotnych. $Z$ kolei pod pojęciem zatrudnienia wspieranego, zgodnie $\mathrm{z}$ art. $24 \mathrm{uwz}$, występują: zatrudnienie subsydiowane, nabycie kwalifikacji zawodowych w miejscu pracy, rotacja pracy oraz prace publiczne.

Poniżej dodatkowe komentarze zostaną przedstawione w odniesieniu do wybranych rozwiązań pomocowych ze względu na ich szczególne znaczenie z punktu widzenia zastosowania względem osób starszych.

Zatrudnienie subsydiowane kierowane jest do osób objętych dodatkowym wsparciem na rynku pracy, w tym do osób powyżej 50. roku życia, zdolnych do pracy (pkt 38.7 zarządzenia w sprawie zasad oraz procedur wprowadzania w życie środków aktywnej polityki rynku pracy ${ }^{19}$ ). Wspieranie zatrudnienia powyższych osób polega na przyznaniu dofinansowania w wysokości $50 \%$ poniesionych w związku z zatrudnieniem wydatków, przez okres nie dłuższy niż 6 miesięcy. Tytułem porównania należy podkreślić, że w przypadku osób niepełnoprawnych dofinansowaniu podlega nawet do $75 \%$ poniesionych wydatków przez maksymalny okres zatrudnienia (pkt 39 zarządzenia). Z kolei w odniesieniu do rozwiązania pomocowego, polegającego na wspieraniu nabywania kwalifikacji zawodowych oraz dofinansowywania wynagrodzeń, nie wskazano wyraźnie osób starszych jako grupy docelowej. Jako adresatów rozwiązania pomocowego wymieniono osoby będące bezrobotnymi długotrwale oraz osoby pozostające bez pracy przez okres powyżej dwóch lat przed rejestracją w urzędzie pracy (pkt 47 zarządzenia).

W zarządzeniu Dyrektora Urzędu Pracy przy Ministerstwie Pracy i Polityki Społecznej z dnia 14 sierpnia 2014 r. wśród kryteriów kwalifikujących do udziału w usługach aktywnej polityki rynku pracy, branych pod uwagę w pierwszej kolejności, wymienia

18 Dalej jako uwz.

19 Lietuvos Respublikos Socialinès Apsaugos ir Darbo Ministro ịsakymas Dèl aktyvios darbo rinkos politikos priemoniu igyvendinimo sąlygų ir tvarkos aprašo patvirtinimo $2009 \mathrm{~m}$. rugpjūčio $13 \mathrm{~d}$., Nr. A1-499, http://www3.lrs.lt/pls/inter3/dokpaieska.showdoc_l?p_id=350927\&p_query=\&p_tr2 (dostęp: 31.01.2016). 
się: wcześniejsze niekorzystanie $\mathrm{z}$ usług, długotrwałe zarejestrowanie w urzędzie pracy oraz posiadanie kwalifikacji, na które występuje zapotrzebowanie ${ }^{20}$.

Rotacja pracy, o której mowa w ustawie, stanowi jeden z elementów wspierania zatrudnienia. Polega ona na czasowym zatrudnieniu osób bezrobotnych, skierowanych przez terytorialnie właściwe urzędy pracy. Chodzi jednak o zatrudnienie ich na stanowiskach pracy pracowników korzystających z urlopów celowych albo innych, wskazanych w układach zbiorowych pracy. Świadczenia przyznawane pracodawcom obejmują w tym przypadku finansowanie wynagrodzeń oraz częściowe finansowanie obowiązkowych składek na ubezpieczenia społeczne z zastrzeżeniem, że wysokość pomocy nie może przekraczać dwukrotności kwoty minimalnego wynagrodzenia w przypadku zatrudnienia osób korzystających ze szczególnego wsparcia na rynku pracy (w tym osób powyżej 50. roku życia) oraz obejmuje 50-70\% obliczonych wydatków.

Na uwagę zasługuje też wspieranie regionalnego przepływu bezrobotnych. Chodzi tutaj o art. $33 \mathrm{uwz}$, zgodnie z którym powyższy środek aktywnej polityki zatrudnienia jest stosowany w celu promowania zatrudnienia poza miejscem zamieszkania, jeżeli właściwy terytorialnie urząd pracy nie może zapewnić odpowiedniej pracy. Bezrobotnym, zatrudnionym w instytucjach bądź zakładach oddalonych od miejsca zamieszkania, finansuje się podróż (dojazd i powrót) do miejsca pracy oraz koszty zamieszkania przez okres nie dłuższy niż 3 miesiące. Miesięczna kwota dofinansowania na dojazd do miejsca pracy nie może przekroczyć kwoty $0,5 \%$ minimalnego wynagrodzenia, zatwierdzonego przez rząd RL. Warunkiem przyznania dofinansowania jest jednak to, by miesięczne koszty podróży przekraczały $20 \%$ wynagrodzenia otrzymywanego przez zatrudnionego, o ile otrzymywane wynagrodzenie jest niższe od kwoty sumy dwóch wynagrodzeń minimalnych. Koszty zakwaterowania podlegają zwrotowi, o ile wyjazd do miejsca pracy odbywa się nie częściej niż raz tygodniowo.

W tym miejscu na podkreślenie zasługuje również profilowanie pomocy dla osób bezrobotnych oraz ustalanie indywidualnych programów zatrudnienia. Ogólnie jednak powyższe rozwiązania są stosowane dla osób posiadających mniejsze doświadczenie zawodowe oraz absolwentów. Preferencyjne potraktowanie powyższych kategorii bezrobotnych potwierdzają przepisy nakładające na podmioty zobowiązane do ustalenia indywidualnych programów, podjęcia działań w możliwie najszybszym czasie. Przykładowo, indywidualne plany zatrudnienia dla osób do 29. roku życia powinny być ustalane w okresie miesiąca, natomiast dla osób powyżej 29. roku życia w okresie trzech miesięcy od zarejestrowania się w urzędzie pracy.

Podkreślenia wymaga to, że szczególnym rodzajem wsparcia dla grup bezrobotnych w wieku starszym są projekty współfinansowane ze środków Europejskiego Funduszu Społecznego. Obejmują one dostępne dla różnych grup usługi rynku pracy, ale ich

20 Lietuvos darbo biržos prie socialinès apsaugos ir darbo ministerijos direktorius įsakymas dèl aktyvios darbo rinkos politikos priemonių igyvendinimo atrankos kriterijų tvarkos aprašo patvirtinimo 2014 m. rugpjūčio 14 d. Nr. v-499, https://www.e- tar.lt/portal/legalAct.html?documentId=396cbaf023 b411e4a6deb7cdea22d38c (dostęp: 31.01.2016). 
adresatami czyni się częstokroć określone docelowe grupy bezrobotnych. Tytułem przykładu należy wskazać na program adresowany wyłącznie do osób powyżej 54. roku życia, zatytułowany „Wsparcie dla osób bezrobotnych w wieku starszym”, realizowany w latach 2015-2017. Uczestnikami projektu mogą być osoby, które ukończyły 55 lat oraz zarejestrowały się w urzędzie pracy. Wśród środków, mających na celu wspieranie zatrudnienia tych osób, wskazano na naukę zawodu, zatrudnienie subsydiowane oraz terytorialny przepływ bezrobotnych. Na chwilę obecną z oferowanego wsparcia skorzystało jedynie nieco ponad 1000 bezrobotnych. Celem projektu jest jednakże pomoc w pozyskaniu zatrudnienia dla 14 tysięcy osób ${ }^{21}$.

Kolejny projekt adresowany między innymi do osób powyżej 54. roku życia, zatytułowany „Zdobądź odpowiedni zawód”, główny nacisk kładł na naukę zawodu. Okres realizacji projektu przypadał na lata 2014-2016.

Na uwagę zasługują również projekty dotyczące wydłużenia aktywności zawodowej osób starszych, w których jedną z grup docelowych stanowią bezrobotni w wieku produkcyjnym powyżej 50. roku życia. Projekt zatytułowany „Pozostań na rynku pracy” realizowany był w latach 2014-2015. Ze względu na cel określony w projekcie wśród środków służących jego realizacji wymieniono naukę zawodu, zatrudnienie subsydiowane, wspieranie nabycia umiejętności zawodowych w miejscu pracy oraz rotację pracy ${ }^{22}$.

Wśród projektów finansowanych ze środków Europejskiego Funduszu Socjalnego, których okres zakończenia realizacji przypadł w roku 2014, sfinalizowanych pomyślnie, wskazać należy na projekt „Pomoc w zatrudnieniu”, adresowany do osób objętych dodatkowym wsparciem na rynku pracy ${ }^{23}$, zagrożonych długotrwałym bezrobociem, zarejestrowanych od sześciu miesięcy w terytorialnie właściwym urzędzie pracy. $\mathrm{W}$ ramach projektu oferowano usługi zatrudnienia subsydiowanego oraz wspieranie nabycia umiejętności zawodowych w miejscu pracy ${ }^{24}$.

Na marginesie należy zauważyć, że do ważnych oraz odgrywających szczególną rolę rozwiązań prawnych, stanowiących podstawę realizowanych projektów, adresowanych do osób starszych ze względu na cel w postaci uczenia się przez całe życie, należy zaliczyć ustawę z 30 czerwca 1998 r. w sprawie nieformalnego uczenia się oraz kontynuacji nauki przez osoby w wieku starszym ${ }^{25}$.

Pewne szczególne rozwiązanie na rzecz starszych osób pozostających bez pracy stanowi również opracowanie bazy danych osób starszych, zainteresowanych poszukiwaniem pracy. Chodzi o umieszczanie danych tych osób w tak zwanym Banku Seniorów. Bank

${ }^{21}$ https://www.ldb.lt/Informacija/ESParama/Puslapiai/vyresnio_amziaus_bed_remimas.aspx (dostęp: 31.01.2016).

22 https://www.ldb.lt/Informacija/ESParama/Puslapiai/esf_islik_darbo_rinkoje.aspx (dostęp: 31.01.2016).

${ }^{23}$ O tym w dalszej części opracowania.

24 https://www.ldb.lt/Informacija/ESParama/gyvendinti\%20ES\%20projektai/UserDispForm. aspx?ID=29 (dostęp: 31.01.2016).

25 Lietuvos respublikos neformaliojo suaugusiųjų švietimo ịstatymo, Nr. VIII-822. Ostatnio znowelizowana ustawą nr viii-822 pakeitimo įstat ymas $2014 \mathrm{~m}$. liepos $10 \mathrm{~d}$. nr. xii-1018. 
ma na celu pomoc w poszukiwaniu pracy przez osoby w wieku starszym (powyżej 50 lat) oraz osoby w wieku emerytalnym. W istocie chodzi tu o stworzenie internetowej bazy danych, w ramach której osoby zainteresowane pozyskaniem pracy rejestrują się elektronicznie na stronie właściwego urzędu, wypełniając formularz, oraz oczekują na zgłoszenia ze strony pracodawców zainteresowanych zatrudnieniem przede wszystkim osób w powyższym przedziale wiekowym.

Podsumowując, warto przytoczyć dane statystyczne, wskazujące na liczby osób bezrobotnych powyżej 50. roku życia, zarejestrowanych w poszczególnych latach:

- w roku 2010 - 81 096;

- w roku 2011 - 70 187;

- w roku 2012 - 64332 ;

- w roku 2013 - 65 066;

- w roku 2014 - 61040.

Z kolei liczba osób powyżej 54. roku życia, zarejestrowanych w roku 2015, wyniosła 63256 (dane na koniec stycznia) oraz 32973 (dane na koniec sierpnia) ${ }^{26}$.

Z danych statystycznych według stanu na dzień 1 maja 2015 r. wynika również, że wśród 155600 zarejestrowanych bezrobotnych $20 \%$ stanowiły osoby powyżej 54 . roku życia, przy czym co druga z tych osób była bezrobotna długotrwale ${ }^{27}$. Stąd też wiele projektów, o których była mowa wcześniej, kierowanych jest przede wszystkim do grupy osób będących długoterminowo bezrobotnymi (art. 2 ust. 11 uwz) ${ }^{28}$. Pod pojęciem tym występują osoby powyżej 25. roku życia, jeżeli pozostają bez pracy przez okres powyżej 12 miesięcy, licząc od dnia rejestracji w urzędzie pracy (w odniesieniu do osób do 25. roku życia okres ten wynosi powyżej 6 miesięcy).

\section{Świadczenia z tytułu bezrobocia}

Świadczenie z tytułu bezrobocia na mocy ustawy o wspieraniu zatrudnienia z 15 czerwca 2006 r. przysługuje osobie bezrobotnej w rozumieniu art. 2 ust. 3 ustawy. Z kolei szczegółowe warunki przyznawania świadczenia określa ustawa z dnia 16 grudnia $2003 \mathrm{r}$. w sprawie ubezpieczenia na wypadek bezrobocia ${ }^{29}$. Zgodnie z jej art. 5 prawo do zasiłku mają osoby bezrobotne, ubezpieczone zgodnie z art. 4 powyższej ustawy, zarejestrowane w terytorialnie właściwym urzędzie pracy, które nie otrzymały od urzędu odpowiedniej pracy albo środków aktywnej polityki rynku pracy, jeżeli przed rejestracją w urzędzie pracy opłacane były składki na ubezpieczenie na wypadek bezrobocia przez okres co najmniej 18 miesięcy w trakcie ostatnich 36 miesięcy. Zgodnie $\mathrm{z}$ artykułem 7 powyższej

26 https://www.ldb.lt/Informacija/DarboRinka/Puslapiai/rodikliai_men_pabaigoje.aspx (dostęp: 31.01.2016).

27 Tamże.

28 https://www.ldb.lt/Informacija/ESParama/Puslapiai/esf_ilgalaik_bedarb_remimas.aspx (dostęp: 31.01.2016).

29 Nedarbo socialinio draudimo istatymas of 16 December 2003 (No. IX-1904).Valstybinio socialinio draudimo įstatymas of 21 May 1991 (No. I-1336). 
ustawy zasiłek dla bezrobotnych jest uzależniony od liczby lat, w trakcie których opłacane były składki przed rejestracją w urzędzie pracy. Jeśli składki były opłacane:

- przez mniej niż 25 lat, zasiłek będzie wypłacany przez 6 miesięcy;

- od 25 do 30 lat, zasiłek będzie wypłacany przez 7 miesięcy;

- od 30 do 35 lat, zasiłek będzie wypłacany przez 8 miesięcy;

- ponad 35 lat, zasiłek będzie wypłacany przez 9 miesięcy.

Podkreślenia wymaga fakt, że na podstawie art. 14 ustawy wprowadzono możliwość wydłużenia okresu pobierania zasiłku dla bezrobotnych. Jeśli ubiegającemu się o zasiłek pozostało maksymalnie 5 lat do osiągnięcia wieku emerytalnego, wypłatę zasiłku wydłuża się o kolejne 2 miesiące. Wydłużenie pobierania zasiłku obwarowane jest jednak niepobieraniem wcześniejszej emerytury, wypłacanej na podstawie przepisów o wcześniejszej emeryturze.

Z kolei zasiłek nie będzie wypłacany, gdy:

- osoba ubiegająca się odmówi przyjęcia oferty pracy zgodnej z kwalifikacjami i stanem zdrowia;

- osoba ubiegająca się odmawia korzystania z usług przewidzianych w indywidualnym planie działania;

- osoba ubiegająca się nie zgłasza gotowości do podjęcia pracy lub nie uczestniczy w realizacji indywidualnego planu działania;

- osoba ubiegająca się odmawia poddania się badaniom mającym na celu ustalenie zdolności do pracy.

Zasiłek dla bezrobotnych składa się z części stałej i zmiennej. Część stała jest to kwota dochodu kwalifikowanego dla pomocy społecznej w danym miesiącu. Część zmienna jest obliczana w następujący sposób:

1) na początku obliczany jest miesięczny ubezpieczony dochód osoby bezrobotnej w ciągu 36 miesięcy poprzedzających koniec ostatniego kwartału przed zarejestrowaniem się w urzędzie pracy;

2) ustalany jest przeciętny współczynnik tego ubezpieczonego dochodu w danym miesiącu;

3) przeciętny współczynnik jest mnożony przez ubezpieczony dochód w miesiącu, w którym ma być wypłacany zasiłek;

4) zmienna część zasiłku to $40 \%$ kwoty z pkt. 3.

Przez pierwsze 3 miesiące osoba bezrobotna otrzymuje pełną kwotę zasiłku, przez pozostały okres - część stałą i 50\% części zmiennej. Od 2015 r. maksymalnie zasiłek dla bezrobotnych mógł wynieść 1041,60 Lt (około 301,67 euro).

\section{Rola partnerów społecznych}

Instytucje i zakłady samorządu terytorialnego biorą udział we wdrażaniu środków aktywnej polityki rynku pracy i opracowują oraz wdrażają programy na rzecz zatrudnienia (art. 9 ustawy o wspieraniu zatrudnienia). Opracowywanie oraz wdrażanie programów na rzecz zatrudnienia zgodnie $\mathrm{z}$ art. 34 uwz obejmuje: prewencję przed bezrobociem, terytorialne wspieranie zatrudnienia, promocję terytorialnego przemieszczania się 
mieszkańców, wejście na rynek pracy imigrantów oraz mniejszości narodowych, wspieranie zatrudnienia szczególnych grup, określonych w art. 4 ust. 1 ustawy (w tym osób powyżej 50. roku życia). Udział we wdrażaniu środków aktywnej polityki rynku pracy, zgodnie $\mathrm{z}$ art. 28, 31 i $32 \mathrm{uwz}$, polega na organizowaniu prac publicznych, wdrożeniu projektów dotyczących miejscowych inicjatyw zatrudnienia (chodzi o tworzenie nowych miejsc pracy na czas nieokreślony) oraz wspieraniu samozatrudnienia.

Na podstawie art. 10 uwz partnerzy społeczni, wdrażając politykę wspierającą zatrudnienie, uczestniczą poprzez udział w radach trójstronnych, działających przy instytucjach zajmujących się wdrożeniem polityki na rzecz zatrudnienia. Wśród zadań wyżej wymienionych rad trójstronnych wskazać należy przedstawianie propozycji odnośnie do kierunków działalności instytucji, programów na rzecz zatrudnienia, określania środków wdrażających politykę zatrudnienia oraz zwiększenia efektywności działalności. Rady trójstronne mogą działać jako ciała stałe bądź mogą być powoływane ad hoc w celu rozwiązywania konkretnych problemów dotyczących wdrożenia polityki zatrudnienia. Zasady działalności rad trójstronnych zatwierdza Ministerstwo Ochrony Socjalnej oraz Minister Pracy.

Przedstawiciele organizacji oraz miejscowej wspólnoty, reprezentujący interesy grup poszukujących pracy, mogą uczestniczyć w radach trójstronnych z głosem doradczym oraz przedstawiać instytucjom wdrażającym politykę zatrudnienia propozycje odnośnie do rozwiązywania problemów zatrudnienia dotyczących osób poszukujących pracy (art. $11 \mathrm{uwz}$ ).

\section{Prawo do emerytury}

Wyróżnia się emerytury wcześniejsze oraz emerytury starcze. Warunki przyznawania i wypłacania powyższych emerytur przewidują: ustawa o państwowych emeryturach $\mathrm{z}$ ubezpieczenia społecznego $\mathrm{z}$ dnia 18 lipca $1994 \mathrm{r}^{30}$ oraz ustawa o wcześniejszych emeryturach z dnia 16 października $2003 \mathrm{r}^{31}$ Nie występuje emerytura częściowa. Od emerytur nie odprowadza się podatku oraz nie są opłacane składki. Osoba będąca w wieku emerytalnym i mająca opłacaną składkę ubezpieczeniową przez co najmniej 15 lat ma prawo do otrzymania emerytury starczej. Wiek emerytalny kobiet i mężczyzn różni się: dla kobiet w 2015 r. wynosi 61 lat i 4 miesiące, dla mężczyzn 63 lata i 2 miesiące. Zarówno dla kobiet, jak i mężczyzn, urodzonych po 1961 r., wiek emerytalny wynoszący 65 lat przypadnie w 2026 r. ${ }^{32}$ Otrzymanie emerytury w maksymalnej wysokości wiąże się z potrzebą przepracowania co najmniej 30 lat. W Republice Litewskiej występują

\footnotetext{
30 Valstybiniu socialinio draudimo pensiju istatymas of 18 July 1994 (No. I-549).

${ }^{31}$ Valstybiniu socialinio draudimo senatvès pensiju išankstinio mokejjimo istatymas of 16 October 2003 (No. IX-1828).

${ }^{32}$ Lietuvos Respublikos Vyriausybès 2011 m. liepos 13 d. nutarimas Nr. 836, dostępna na http:// www.pensijusistema.lt/index.php?619557871 (dostęp: 31.01.2016).
} 
także emerytury szczególne, emerytury inwalidzkie (ze względu na utratę zdolności do pracy), emerytury państwowe oraz emerytury dla naukowców.

Wysokość emerytury starczej uzależniona jest od stażu pracy, otrzymywanych dochodów oraz ustalonej przez rząd RL w bieżącym roku wysokości kwoty przychodów opodatkowanych oraz emerytury bazowej. Emerytura składa się z trzech części: podstawowej, dodatkowej oraz dodatku stażowego ${ }^{33}$. Wysokość podstawowej emerytury zależy od decyzji rządu i jest opracowywana z uwzględnieniem inflacji. Dla osób mających 30-letni staż pracy podstawowa część emerytury wynosi około 118,8 euro (110\% emerytury bazowej). Dodatkowa część emerytury zależy natomiast od długości okresu ubezpieczenia oraz wysokości otrzymywanych dochodów. Część dodatkową oblicza się, mając na uwadze zarówno cały dotychczasowy staż pracy, jak i ustaloną przez rząd RL w bieżącym roku wysokość kwoty przychodów opodatkowanych. W bieżącym roku wynosi ona 434 euro. Dodatek za staż pracy wypłacany jest osobom mającym ponad 30 -letni staż pracy. Obliczany jest on za każdy pełny rok pracy powyżej 30 lat oraz wynosi 3,24 euro za każdy rok stażu (3\% kwoty emerytury bazowej). Średnia emerytura dla osób z 30-letnim stażem wynosi około 250,10 euro, natomiast dla tych nieposiadających obowiązkowego stażu około 140,20 euro. Podkreślenia wymaga fakt, że osoby, które otrzymują emeryturę starczą, mogą pracować bez ograniczeń. Emerytura nie będzie wówczas zmniejszana.

Z kolei emerytura wcześniejsza jest wypłacana w sytuacji, gdy do nabycia prawa do emerytury brakuje nie więcej niż 5 lat do osiągnięcia wieku emerytalnego oraz pod warunkiem, że osoba posiada co najmniej 30-letni staż ubezpieczeniowy. Wyjątek od wymogu spełnienia powyższego stażu dotyczy osób, które urodziły i wychowały w okresie 8 lat pięcioro bądź więcej dzieci, a także osób sprawujących opiekę nad osobami zależnymi. W stosunku do nich przewidziano wymóg posiadania 15-letniego stażu ubezpieczeniowego. Dodatkowym warunkiem jest jednak to, by osoby nie otrzymywały dodatkowych dochodów (wypłat okresowych, świadczeń z pomocy społecznej) oraz nie pracowały, jak i nie prowadziły działalności rolniczej. W związku z powyższym w razie podjęcia zatrudnienia albo pracy na własny rachunek wypłata emerytury wcześniejszej będzie wstrzymywana.

Wysokość emerytury wcześniejszej uzależniona jest od stażu pracy, otrzymywanych dochodów oraz ustalonej przez rząd RL w bieżącym roku wysokości kwoty przychodów opodatkowanych. Emerytura wcześniejsza jest obliczana tak jak emerytura pełna, jednakże ulega ona zmniejszeniu za każdy pełny miesiąc pozostający do osiągnięcia wieku emerytalnego o 0,4\%. Mechanizm ten ma zniechęcać do przechodzenia na wcześniejszą emeryturę. Przykładowo, w przypadku otrzymywania emerytury wcześniejszej przez okres 5-letni (60-miesięczny) obliczona emerytura wynosi 240 euro. Jednakże rzeczywiście wypłacona kwota będzie o $24 \%$ mniejsza $(60$ x $0,4 \%=24 \%)$ i wyniesie około 182,40 euro.

${ }^{33}$ Zob. też A. Mažionienė, D. Valeckienė, I. Mažionytė, D. Beržinyte, T. Aleksandravičiutė, D. Bliudžiute, R. Razmute, K. Zakarauskaite, Ageing in Lithuania, Klaipeda 2011, s. 14, 15, http://www.mep_ activeageing.ipleiria.pt/files/2012/01/Klaipeda-State-College1.pdf (dostęp: 31.01.2016). 
Średnia emerytura wcześniejsza wynosi obecnie 175,14 euro. Ze względu na to, że od 2012 r. wiek emerytalny jest stopniowo wydłużany (dla mężczyzn jest wydłużany o 4 miesiące, dla kobiet o 2 miesiące), jest to decydujące dla nabycia prawa do emerytury wcześniejszej ${ }^{34}$.

\section{Uwagi końcowe}

Osoby w wieku powyżej 50 lat stanowią grupę objętą szczególnym wsparciem na rynku pracy, do której stosuje się aktywne środki przeciwdziałania bezrobociu. Niemniej zasadniczo nie występują środki prawne adresowane wyłącznie do osób starszych (wyjątek dotyczy Banku Seniorów oraz niektórych programów, współfinansowanych ze środków Europejskiego Funduszu Społecznego). Odmienne warunki udzielania pomocy w związku z aktywizacją zawodową osób starszych sprowadzają się głównie do wydłużenia okresu przyznawania świadczeń (przykład - zasiłek z tytułu bezrobocia). Wydłużony okres przyznawania subsydiów bądź wysokość dofinansowania uzależnione są częstokroć od spełnienia dodatkowych warunków (przykładowo chodzi o posiadanie określonego stopnia niepełnosprawności bądź dłuższe pozostawanie bez pracy albo zwolnienie z przyczyn ekonomicznych, niedotyczących pracownika). Na szczególne podkreślenie zasługuje także to, że większość środków wspierających zatrudnienie adresowanych jest do pracodawców zatrudniających osoby niepełnosprawne. Stąd posiadanie stopnia niepełnosprawności przez osobę starszą otwiera dla niej możliwość korzystania $\mathrm{z}$ dodatkowego wsparcia $\mathrm{w}$ realizacji powrotu na rynek pracy.

Nie występują również szczególne środki zachęcające pracodawców do zatrudnienia osób w wieku starszym. Litewski kodeks pracy zawiera unormowania w zakresie ochrony zatrudnienia starszych pracowników. Dla nich przewidziano też dłuższe okresy wypowiedzenia oraz większą rekompensatę za utratę pracy. Brakuje jednak szczegółowych rozwiązań odnoszących się do zwiększania zatrudnienia osób w wieku przedemerytalnym albo emerytów. Tym samym do starszych pracowników stosowane mogą być ogólne rozwiązania, właściwe dla wszystkich pozostałych osób zatrudnionych w ramach stosunku pracy. Ewentualne bardziej korzystne postanowienia mogą być wprowadzane na mocy układu zbiorowego pracy. W praktyce stosowane są bowiem rozwiązania polegające na wprowadzeniu dodatków stażowych, a także dłuższych urlopów dla starszych pracowników.

W ramach głównych zaleceń dotyczących zwiększenia aktywności zawodowej osób starszych wskazuje się na stworzenie dla nich takich warunków, by praca mogła być godzona z obowiązkami rodzinnymi, stanem zdrowia oraz możliwościami psychofizycznymi. Odradza się pracę w porze nocnej oraz pracę zmianową, zalecając w związku z powyższym wprowadzenie:

$34 \mathrm{http} / /$ www.sodra.lt/lt/situacijos/informacija-gyventojams/noriu-gauti-pensija/senatves-pensija (dostęp: 31.01.2016). 
- pracy w niepełnym wymiarze czasu pracy - dotyczy to zarówno osób w wieku emerytalnym, jak i osób w wieku przedemerytalnym, jeżeli mają dodatkowe dochody albo jeżeli otrzymują płacę powyżej minimalnej;

- elastycznego czasu pracy, w tym prawa do częstszych, ale krótszych przerw;

- elastycznych zasad udzielania urlopu wypoczynkowego, możliwości dzielenia urlopu na części;

- przejścia na niepełny wymiar czasu pracy na wniosek pracownika;

- częściowej bądź periodycznej wypłaty wynagrodzenia za część wykonanej pracy;

- elastycznego miejsca pracy ${ }^{35}$.

Podkreślenia w tym miejscu wymaga to, że część z wyżej wymienionych rozwiązań uwzględniono w wyniku wprowadzenia nowego litewskiego Kodeksu pracy. Jednakże, jak zauważono wcześniej, większość z nich ma zastosowanie do ogółu pracowników. Nie występują zatem środki prawne w zakresie elastycznych rozwiązań prawnych adresowane wyłącznie do starszych pracowników.

Zauważa się, że spadek liczby osób starszych w rejestrze bezrobotnych jest konsekwencją większego zaangażowania służb zatrudnienia między innymi w wyniku pomyślnie realizowanych projektów współfinansowanych ze środków Europejskiego Funduszu Społecznego, skierowanych do osób starszych jako grupy docelowej. Badania pokazują jednak, że większość z osób powyżej 50. roku życia wykazuje chęć podejmowania pracy oraz dłuższego pozostawania na runku pracy w zasadzie wyłącznie z powodów ekonomicznych (78\% respondentów). Podkreśla się w związku z powyższym, że wzrost zatrudnienia osób w wieku emerytalnym jest bardziej wynikiem niskiej emerytury, aniżeli efektywnej, aktywnej polityki zatrudnienia. Podobnie zatem, gdy chodzi o dłuższe pozostanie na rynku pracy osób w wieku przedemerytalnym, spowodowane jest to niekorzystnymi warunkami dotyczącymi emerytury wcześniejszej oraz jej wpływem na wysokość emerytury starczej.

Wśród głównych przyczyn wyhamowujących dłuższe pozostawanie na rynku pracy znajdują się dyskryminacja ze względu na wiek, problemy zdrowotne oraz obawy przed zmianami ze strony starszych pracowników. W związku z powyższym podkreśla się potrzebę zwiększenia roli układów zbiorowych pracy w zakresie kształtowania warunków pracy starszych pracowników, a także zwiększenie udziału partnerów społecznych w kształtowaniu polityki i instrumentów prawnych służących aktywizacji osób starszych. W tym zakresie postuluje się zwiększenie znaczenia polityki zarządzania

${ }_{35}$ Zob. wnioski sformułowane w ramach projektu: Vyresnio amžiaus moterų ir vyrų lankstaus darbo metodai ir praktinis taikymas, vši „socializacijos ir darbinio mokymo centras” igyvendinamo projekto „socialinę riziką ir socialinę atskirtị patiriančių asmenų integracija ị darbo rinką taikant lankstaus darbo modelị”, nr. vp1(1.3(sadm(02(k(01(020, Vilnius 2009, s. 15, http://www.sidmc.org/project_020/ wp-content/uploads/IV_vyresni_zmones_santrauka.pdf (dostęp: 31.01.2016). Finansowanie projektu: Projektas finansuojamas iš ES 2007 - 2013 metų Žmogiškųjų išteklių pletros veiksmų programos 1 prioriteto „Kokybiškas užimtumas ir socialine apruptis” VP1(1.3(SADM(02 priemones „Socialines rizikos ir socialinę atskirtị patiriančių asmenų integracija ị darbo rinką").

36 R. Zabarauskaite, I. Blaziene, European Observatory of Working Life, Lithuania... 
wiekiem poprzez dostosowywanie stanowiska pracy oraz grafiku pracy do możliwości starszych pracowników. Chodzi tu także o branie tego pod uwagę przy tworzeniu nowych stanowisk pracy albo przy dostosowaniu już istniejących. Zauważa się, że do dłuższego utrzymania starszych pracowników na rynku pracy z pewnością przyczyni się zmiana w odbiorze społecznym osób starszych oraz wypracowanie opinii o osobach starszych jako mentorach oraz osobach przekazujących doświadczenie młodszym pracownikom ${ }^{37}$.

W uchwale przyjętej przez rząd Republiki Litewskiej wskazano na główne kierunki aktywizacji osób od 20. do 64. roku życia ${ }^{38}$. Główny cel strategiczny stanowi osiągnięcie wyższych wskaźników zatrudnienia poprzez stworzenie możliwości znalezienia odpowiedniej do kwalifikacji pracy, zapewniającej jednocześnie godne utrzymanie. Wśród celów szczegółowych wymieniono promocję tworzenia miejsc pracy zwłaszcza w tych regionach, w których występuje wysoki poziom bezrobocia, a także zachęcanie do uczenia się przez całe życie jako najważniejszej gwarancji utrzymania się na rynku pracy ${ }^{39}$.

Artykut stanowi opracowanie, realizowane $w$ ramach projektu naukowego pod tytułem „W poszukiwaniu modelu środków prawnych przeciwdziałania bezrobociu wśród osób starszych - analiza prawna", finansowanego przez Narodowe Centrum Nauki, DEC-2013/09/B/HS5/04137.

Artykuł przedstawia stan prawny na maj 2017 roku.

\section{Bibliografia}

Baginskas T., Usonis J., Problems of introduction of flexibility into Lithuanian labour law, Jurisprudence 2011, 18 (2).

Brazienė R., Mikutavičienė I., Dorelaitienė A., Žalkauskaitė U., Jurkevičienė J., Vyresnio amžiaus žmoniu (socialinès ịtraukites) ì(si)traukimo ị darbo rinka galimybių atsakaita, 2014 m., www. lygybe.lt (dostęp: 31.01.2016).

Lengvinienè S., Rutkienė A., Tandzegolskienè I., Vyresnio amžiaus asmenų išlikimo darbo rinkoje teoriniai aspektami, Profesinis rengi mas: tyrimai ir realijos 2014, 25.

Mažionienė A., Valeckienė D., Mažionytė I., Beržinytė D., Aleksandravičiutė T., Bliudžiutė D., Razmute R., Zakarauskaitè K., Ageing in Lithuania, Klaipeda 2011.

${ }^{37}$ S. Lengvinienė, A. Rutkienè, I. Tandzegolskienè, Vyresnio amžiaus asmenu išlikimo darbo rinkoje teoriniai aspektami, Profesinis rengi mas: tyrimai ir realijos 2014, 25, s. 135, www.ejournals.vdu.lt/index. php/vocationaltraining/.../250 (dostęp: 31.01.2016).

${ }^{38}$ Lietuvos Respublikos Vyriausybès nutarimas dèl užimtumo didinimo 2014-2020 metų programos patvirtinimo 2013 m., rugsèjo 25 D. Nr. 878.

${ }^{39} \mathrm{O}$ tym szczegółowo A. Rutkiene, S. Lengviniene, Learning as precondition to stay active in labour market for elder people, Society. Integration. Education, Proceedings of the international scientific conference. Volume iv, may 27th-28th 2016, s. 132-143, http://journals.ru.lv/index.php/sie/article/viewfile/1536/1757 (dostęp: 31.01.2016). 
Navaitis G., Burneikienė A., Trinkūnienė R., Lygiu galimybiu pažeidimai (amžiaus aspektas), Socialinis Darbas 2008, 7 (3).

Petrylaite D., Four year of Lithuanian labour reforms, Lithuanian national report, International Society for Labour and Social Security 2014.

Rutkiene A., Lengviniene S., Learning as precondition to stay active in labour market for elder people, Society. Integration. Education, Proceedings of the international scientific conference. Volume iv, may 27th-28th 2016 http://journals.ru.lv/index.php/sie/article/ viewfile/1536/1757 (dostęp: 31.01.2016).

Zabarauskaite R., Blaziene I., European Observatory of Working Life, Lithuania: The role of governments and social partners in keeping older workers in the labour market, Institute of Labour and Social Research, opublikowano 2.06.2013 r., http://www.eurofound.europa.eu/ observatories/eurwork/comparative-information/national-contributions/lithuania-the-role-of-governments-and-social-partners-in-keeping-older-workers-in-the-labour-market (dostęp: 31.01.2016). 